\title{
Anti-inflammatory Effects of Extracts and Their Solvent Fractions of Rice Wine Lees
}

\author{
Mi-Jeong Park ${ }^{1}$, Hyung-Taek Kang ${ }^{1}$, Mi-Sun Kim², Woo-Chang Shin ${ }^{3}$, Ho-Yong Sohn ${ }^{2}$ and Jong-Sik Kim ${ }^{1 *}$ \\ ${ }^{1}$ Department of Biological Sciences, Andong National University, Andong 760-749, Korea \\ ${ }^{2}$ Department of Food and Nutrition, Andong National University, Andong 760-749, Korea \\ ${ }^{3}$ Research Institute, Kooksoondang Brewery Co, Ltd, Seongnam 460-120, Korea
}

Received May 10, 2014 /Revised May 26, 2014 /Accepted May 26, 2014

\begin{abstract}
In the current study, we prepared eighty-five different kinds of solvent fractions of rice wine lees and nuruk extracts and investigated their effects on cell viability and nitric oxide (NO) production in mouse RAW 264.7 cells. Among the treated solvent fractions, only three solvent fractions (KSD-E1-3, KSD-E2-3 and KSD-E4-3) significantly decreased NO production in LPS-activated RAW 264.7 cells without affecting cell viability. And, they also reduced the expression of pro-inflammatory genes such as COX-2, TNF-alpha and iNOS. To understand the molecular mechanisms involved in the inhibition of inflammation in (KSD-E4-3)-treated RAW 264.7 cells, we carried out oligo DNA microarray analysis using Agilent Mouse microarray. To confirm microarray data, 6 genes (IL-1F6, iNOS, IL-10, Fabp4, IL-1RN and CSF2) were selected and performed RT-PCR and quantitative real-time PCR analysis with gene specific primers. The results of RT-PCR and real-time PCR agreed with microarray data. Overall, our results suggest that rice wine lees can be a novel resource for the development of foods and drugs which possess anti-inflammatory activity.
\end{abstract}

Key words : Anti-inflammation, lees, oligo DNA microarray, pro-inflammatory gene, RAW 264.7 cells

\section{서 론}

주박은 쌀, 물, 누룩, 효모 등을 이용하여 청주나 약주를 빚 은 후 술을 걸러내는 과정에서 생성되는 부산물이다[5]. 양조 과정 중에 첨가되는 주박 미생물들은 균 자체로서 풍부한 영 양분을 함유하고 있다[11]. 현재 우리나라에서 주박은 폐기물 관리법에 의해 산업폐기물로 지정되어 있으며, 양돈업자에 의 해 사료용으로 소비되거나 추가비용을 들여 폐기하는 실정이 다. 주박에 의한 생리활성 연구로는 주박을 섭취한 흰쥐에서 항당뇨 활성이 보고되었고[5], 주박 추출물에 의한 항균, 항산 화 활성에 대해서도 보고되었다[6].

누룩은 술과 발효 식품을 만드는데 사용되는 한국의 전통 발효제(koji)이며[2], 곰팡이, 효모, 일부 박테리아 등 여러 종류 의 미생물이 생장하고 있다[17]. 술의 발효와 숙성 중에 주원료 로 사용되는 호화된 곡물(쌀, 보리, 수수, 옥수수, 대두, 호밀, 귀리 등)의 전분질을 분해[16], 당화시켜 포도당으로 만들어주 는 효소원이자 발효원으로, 알코올 발효의 중요한 원료가 되

\footnotetext{
*Corresponding author

Tel : +82-54-820-5798, Fax : +82-54-820-7705

E-mail : jsk@andong.ac.kr

This is an Open-Access article distributed under the terms of the Creative Commons Attribution Non-Commercial License (http://creativecommons.org/licenses/by-nc/3.0) which permits unrestricted non-commercial use, distribution, and reproduction in any medium, provided the original work is properly cited
}

고 있다. 누룩에 의한 생리활성 연구로는 누룩에서 sterol을 정제하여 암의 전이를 억제한 연구[9]와 염증 억제에 대한 보 고가 있으며[3], 최근에는 누룩의 에탄올 추출물을 처리하여 산화적 스트레스와 멜라닌 분비 그리고 광 피부노화 저해에 관한 연구가 보고되었다[11].

염증(inflammation)은 체내에서 물리적 손상이나 신진대사 의 이상과 같은 다양한 자극에 대한 방어 기작이다[4]. 적절한 염증반응은 생체를 보호하는 필수 불가결한 반응이나, 과도하 고 부적절한 염증반응은 세포 및 조직의 괴사 및 각종 만성질 환의 원인이 된다[7]. 또한 염증은 체내 다양한 기관에서 발생 할 수 있으며, 만성 염증 질환의 경우 암화(carcinogenesis)와 밀접한 관련이 있기 때문에 암으로 발전할 가능성이 있다고 알려져 있다[14].

염증 유도 물질인 lipopolysaccharide (LPS)는 대식세포 표 면의 Toll-like receptor 4 를 자극하여 하부 세포신호전달경로 인 mitogen-activated protein kinase (MAPK)의 활성화를 유 도한다[1]. MAPK 중 extracellular signal-regulated kinase (ERK)와 p38은 LPS로 자극된 iNOS 유도와 대식세포의 NO 생성에 관련이 있는 것으로 잘 알려져 있다[15]. 염증 조절인자 중 하나인 nitric oxide $(\mathrm{NO})$ 는 과량이 존재하면 인체에 유해 한 영향을 미치게 되어 염증반응 및 세포손상 뿐 만 아니라 뇌막염, 알츠하이머병과 파킨슨병 같은 퇴행성 질환의 중요한 발생 요인으로 작용하는 것으로 알려져 있다[13].

본 연구에서는 마우스 대식세포 RAW 264.7 세포주를 모델 
로 8종의 주박과 3종의 누룩을 유기용매로 분획하여 획득한 총 85 종의 분획물에 의한 LPS-유도 염증반응에서의 항염증 활성 및 기전을 연구하고자 하였다. 즉, 마우스 대식세포인 RAW 264.7 세포주에 85종의 분획물을 처리하여 nitric oxide (NO) 생성 여부 및 세포성장에 미치는 영향을 확인하였으며, 분획물에 의한 항염증 기전을 유전체 수준에서 이해하고자 oligo DNA microarray 실험을 수행하여 차별적으로 발현되 는 유전자를 확인하였다. 그 중 염증과 관련된 6 개의 유전자를 선별하였고, 이들 유전자의 발현 변화를 통해 항염증 활성의 관련성을 검증하였다. 이러한 연구 결과는 주박 추출물 및 분 획물에 의한 항염증 활성의 기전을 이해하는데 도움을 줄 것 으로 기대된다.

\section{재료 및 방법}

\section{주박 및 누룩 추출물 제조}

본 연구에서 사용된 8종의 주박과 3종의 누룩은 (주)국순당 에서 제공받아 사용하였다. 총 11 종의 시료에서 총 85 종의 분 획물을 2 회에 나누어 제조하였다. 제조방법은 다음의 절차에 따라 진행하였다. 먼저 주박의 열수 추출물은 시료 $1 \mathrm{~kg}$ 에 물 11 을 가하여 $100^{\circ} \mathrm{C}$ 에서 30 분 동안 추출하였고 여과한 후 (Whatman No. 2), $70^{\circ} \mathrm{C}$ 에서 감압 농축하여 분말로 제조하였 다. 에탄올 추출물은 시료 $1.5 \mathrm{~kg}$ 에 95\% ethanol 61 를 가하여 상온에서 3 일간 2 회 추출 하였고, 여과한 후 $60^{\circ} \mathrm{C}$ 에서 감압 농축하여 분말로 제조하였다. 또한 누룩의 에탄올 추출물은 시료 $200 \mathrm{~g}$ 에 95\% 에탄올 11 를 가하여 상온에서 7일 동안 2 회 추출하였고, 여과한 후 $60^{\circ} \mathrm{C}$ 에서 감압 농축하여 분말로 제조하였다. 각각 추출된 추출물 $4 \mathrm{~g}$ 을 물에 현탁 하여 n-hexane, ethylacetate, butanol을 이용하여 순차적으로 분획하고 물 잔류물을 회수하여 총 85 종의 추출물 및 분획물을 제조하 였다. 추출물과 분획물은 $\mathrm{DMSO}$ 에 녹여 $-20^{\circ} \mathrm{C}$ 에서 저장하여 사용하였다. 분리한 추출물 및 분획물의 list는 1 차, 2 차에 나누 어 각각 Table 1, 2에 나타내었다.

\section{RAW264.7 세포주 배양}

본 연구에 사용된 세포주는 마우스 대식세포 RAW 264.7 세포주를 사용하였고 American Type Culture Collection (ATCC, USA)에서 구입하였다. 세포주의 배양은 Dulbecco's Modified Eagle Medium (DMEM, Gibco, USA)에 10\% Fetal Bovine Serum (FBS, Gibco, USA), 1\% penicillin 및 streptomycin (WelGene, Korea)을 첨가하여 사용하였다.

\section{항염증 활성 측정(Griess reagent assay)}

총 85종의 추출물 및 분획물 들이 마우스 대식세포인 RAW 264.7 세포주의 염증 물질인 nitric oxide (NO) 생성에 미치는 영향을 연구하기 위해 NO 생성을 Griess reagent를 이용하여
Table 1. List of forty kinds of lees extracts and their solvent fractions (1st preparation)

\begin{tabular}{|c|c|c|c|}
\hline NO. & $\begin{array}{c}\text { Alcohol } \\
\text { beverages }\end{array}$ & Extracts & Fractions \\
\hline $\begin{array}{l}\text { KSD-W6-1 } \\
\text { KSD-W6-4 } \\
\text { KSD-W6-5 }\end{array}$ & Y-Ju & \multirow{5}{*}{$\begin{array}{l}\text { Hot water } \\
\text { ex. }\end{array}$} & $\begin{array}{l}\text { Hot water ex. } \\
\text { Buthanol fr. } \\
\text { Water res. }\end{array}$ \\
\hline $\begin{array}{l}\text { KSD-W3-1 } \\
\text { KSD-W3-4 } \\
\text { KSD-W3-5 }\end{array}$ & E-Ju & & $\begin{array}{c}\text { Hot water ex. } \\
\text { Buthanol fr. } \\
\text { Water res. }\end{array}$ \\
\hline $\begin{array}{l}\text { KSD-W1-1 } \\
\text { KSD-W1-4 } \\
\text { KSD-W1-5 }\end{array}$ & M-Ju & & $\begin{array}{c}\text { Hot water ex. } \\
\text { Buthanol fr. } \\
\text { Water res. }\end{array}$ \\
\hline $\begin{array}{l}\text { KSD-W5-1 } \\
\text { KSD-W5-4 } \\
\text { KSD-W5-5 }\end{array}$ & S-Ju & & $\begin{array}{c}\text { Hot water ex. } \\
\text { Buthanol fr. } \\
\text { Water res. }\end{array}$ \\
\hline $\begin{array}{l}\text { KSD-W2-1 } \\
\text { KSD-W2-4 } \\
\text { KSD-W2-5 }\end{array}$ & W-Ju & & $\begin{array}{c}\text { Hot water ex. } \\
\text { Buthanol fr. } \\
\text { Water res. }\end{array}$ \\
\hline $\begin{array}{l}\text { KSD-E6-1 } \\
\text { KSD-E6-2 } \\
\text { KSD-E6-3 } \\
\text { KSD-E6-4 } \\
\text { KSD-E6-5 }\end{array}$ & Y-Ju & \multirow{5}{*}{$\begin{array}{c}80 \% \\
\text { Ethanol ex. }\end{array}$} & $\begin{array}{l}\text { Ethanol ex. } \\
\text { Hexane fr. } \\
\text { Ethylacetate fr. } \\
\text { Buthanol fr. } \\
\text { Water res. }\end{array}$ \\
\hline $\begin{array}{l}\text { KSD-E3-1 } \\
\text { KSD-E3-2 } \\
\text { KSD-E3-3 } \\
\text { KSD-E3-4 } \\
\text { KSD-E3-5 }\end{array}$ & E-Ju & & $\begin{array}{l}\text { Ethanol ex. } \\
\text { Hexane fr. } \\
\text { Ethylacetate fr. } \\
\text { Buthanol fr. } \\
\text { Water res. }\end{array}$ \\
\hline $\begin{array}{l}\text { KSD-E1-1 } \\
\text { KSD-E1-2 } \\
\text { KSD-E1-3 } \\
\text { KSD-E1-4 } \\
\text { KSD-E1-5 }\end{array}$ & M-Ju & & $\begin{array}{l}\text { Ethanol ex. } \\
\text { Hexane fr. } \\
\text { Ethylacetate fr. } \\
\text { Buthanol fr. } \\
\text { Water res. }\end{array}$ \\
\hline $\begin{array}{l}\text { KSD-E5-1 } \\
\text { KSD-E5-2 } \\
\text { KSD-E5-3 } \\
\text { KSD-E5-4 } \\
\text { KSD-E5-5 }\end{array}$ & S-Ju & & $\begin{array}{l}\text { Ethanol ex. } \\
\text { Hexane fr. } \\
\text { Ethylacetate fr. } \\
\text { Buthanol fr. } \\
\text { Water res. }\end{array}$ \\
\hline $\begin{array}{l}\text { KSD-E2-1 } \\
\text { KSD-E2-2 } \\
\text { KSD-E2-3 } \\
\text { KSD-E2-4 } \\
\text { KSD-E2-5 }\end{array}$ & W-Ju & & $\begin{array}{l}\text { Ethanol ex. } \\
\text { Hexane fr. } \\
\text { Ethylacetate fr. } \\
\text { Buthanol fr. } \\
\text { Water res. }\end{array}$ \\
\hline
\end{tabular}

측정하였다. 먼저 RAW 264.7 세포를 96 well plate의 각 well 에 $1 \times 10^{5}$ 개의 세포가 되게 접종한 후, 18 시간 동안 배양하였다. 그 후 lipopolysaccharide (LPS, Sigma, USA)를 $0.2 \mu \mathrm{g} / \mathrm{ml}$ 농 도로 처리하고 1 시간 후 $\mathrm{DMSO}$ 에 녹인 추출물과 분획물을 각각 $500 \mu \mathrm{gg} / \mathrm{ml}$ (1차 40종) 혹은 $150 \mu \mathrm{g} / \mathrm{ml}$ (2차 45종) 으로 처리하여 16 시간 동안 배양하였다. 생성된 NO의 양은 Griess 시약 $1 \%$ sulfanilamide, $0.1 \%$ naphylethylenediamine in $2.5 \%$ phosphoric acid)을 이용해 세포배양액 중 존재하는 $\mathrm{NO}_{2}$ 의 
Table 2. List of forty five kinds of lees extracts and their solvent fractions (2nd preparation)

\begin{tabular}{|c|c|c|c|}
\hline NO. & $\begin{array}{c}\text { Alcohol } \\
\text { beverages }\end{array}$ & Extracts & Fractions \\
\hline KSD-W3-3 & Y-Ju & \multirow{5}{*}{$\begin{array}{c}\text { Hot } \\
\text { water ex. }\end{array}$} & Ethylacetate fr. \\
\hline KSD-W1-3 & $\mathrm{M}-\mathrm{Ju}$ & & Ethylacetate fr. \\
\hline KSD-W5-3 & S-Ju & & Ethylacetate fr. \\
\hline KSD-W2-3 & W-Ju & & Ethylacetate fr. \\
\hline $\begin{array}{l}\text { KSD-W4-1 } \\
\text { KSD-W4-2 } \\
\text { KSD-W4-4 } \\
\text { KSD-W4-5 }\end{array}$ & B-Ju & & $\begin{array}{l}\text { Hot water ex. } \\
\text { Hexane fr. } \\
\text { Buthanol fr. } \\
\text { Water res. }\end{array}$ \\
\hline $\begin{array}{l}\text { KSD-E4-1 } \\
\text { KSD-E4-2 } \\
\text { KSD-E4-3 } \\
\text { KSD-E4-4 } \\
\text { KSD-E4-5 }\end{array}$ & B-Ju & $\begin{array}{l}\quad 80 \% \\
\text { Ethanol ex. }\end{array}$ & $\begin{array}{l}\text { Ethanol ex. } \\
\text { Hexane fr. } \\
\text { Ethylacetate fr. } \\
\text { Buthanol fr. } \\
\text { Water res. }\end{array}$ \\
\hline $\begin{array}{l}\text { KSD-W7-1 } \\
\text { KSD-W7-4 } \\
\text { KSD-W7-5 } \\
\end{array}$ & $\mathrm{RM}-\mathrm{Ju}$ & $\begin{array}{l}\text { Hot water } \\
\text { ex. }\end{array}$ & $\begin{array}{l}\text { Hot water ex. } \\
\text { Buthanol fr. } \\
\text { Water res. }\end{array}$ \\
\hline $\begin{array}{l}\text { KSD-E7-1 } \\
\text { KSD-E7-2 } \\
\text { KSD-E7-3 } \\
\text { KSD-E7-4 } \\
\text { KSD-E7-5 }\end{array}$ & $\mathrm{RM}-\mathrm{Ju}$ & $\begin{array}{l}80 \% \\
\text { Ethanol ex. }\end{array}$ & $\begin{array}{l}\text { Ethanol ex. } \\
\text { Hexane fr. } \\
\text { Ethylacetate fr. } \\
\text { Buthanol fr. } \\
\text { Water res. }\end{array}$ \\
\hline $\begin{array}{l}\text { KSD-E11-1 } \\
\text { KSD-E11-2 } \\
\text { KSD-E11-3 } \\
\text { KSD-E11-4 } \\
\text { KSD-E11-5 }\end{array}$ & E-Nuruk & \multirow{2}{*}{$\begin{array}{l}90 \% \\
\text { Ethanol ex. }\end{array}$} & $\begin{array}{l}\text { Ethanol ex. } \\
\text { Hexane fr. } \\
\text { Ethylacetate fr. } \\
\text { Buthanol fr. } \\
\text { Water res. }\end{array}$ \\
\hline $\begin{array}{l}\text { KSD-E10-1 } \\
\text { KSD-E10-2 } \\
\text { KSD-E10-3 } \\
\text { KSD-E10-4 } \\
\text { KSD-E10-5 } \\
\end{array}$ & M-Nuruk & & $\begin{array}{l}\text { Ethanol ex. } \\
\text { Hexane fr. } \\
\text { Ethylacetate fr. } \\
\text { Buthanol fr. } \\
\text { Water res. }\end{array}$ \\
\hline $\begin{array}{l}\text { KSD-W8-1 } \\
\text { KSD-W8-3 } \\
\text { KSD-W8-4 } \\
\text { KSD-W8-5 }\end{array}$ & SJ-Ju & $\begin{array}{l}\text { Hot water } \\
\text { ex. }\end{array}$ & $\begin{array}{l}\text { Hot water ex. } \\
\text { Ethylacetate fr. } \\
\text { Buthanol fr. } \\
\text { Water res. }\end{array}$ \\
\hline $\begin{array}{l}\text { KSD-E8-1 } \\
\text { KSD-E8-2 } \\
\text { KSD-E8-3 } \\
\text { KSD-E8-4 } \\
\text { KSD-E8-5 }\end{array}$ & SJ-Ju & $\begin{array}{l}\quad 80 \% \\
\text { Ethanol ex. }\end{array}$ & $\begin{array}{l}\text { Ethanol ex. } \\
\text { Hexane fr. } \\
\text { Ethylacetate fr. } \\
\text { Buthanol fr. } \\
\text { Water res. }\end{array}$ \\
\hline $\begin{array}{l}\text { KSD-E9-1 } \\
\text { KSD-E9-2 } \\
\text { KSD-E9-3 } \\
\text { KSD-E9-4 } \\
\text { KSD-E9-5 }\end{array}$ & R4-Nuruk & $\begin{array}{c}80 \% \\
\text { Ethanol ex. }\end{array}$ & $\begin{array}{l}\text { Ethanol ex. } \\
\text { Hexane fr. } \\
\text { Ethylacetate fr. } \\
\text { Buthanol fr. } \\
\text { Water res. }\end{array}$ \\
\hline
\end{tabular}

형태로 측정하였다. 세포 배양 상등액 $100 \mu 1$ 와 Griess 시약 $100 \mu 1$ 를 1:1로 혼합하여 96 well plate에서 15분간 반응시키고 NanoQuant Plate ${ }^{\mathrm{TM}}$ (Tecan Trading AG, Switzerland)를 사용 하여 $540 \mathrm{~nm}$ 에서 흡광도를 측정하였다. 실험결과 수치는 4 개
의 독립적인 well에서 수행한 값을 Microsoft EXCEL program 을 이용하여 분석한 후 mean $\pm \mathrm{SD}$ 값과 그래프로 나타내었다.

\section{세포 성장율 측정(MTS assay)}

주박 추출물 및 분획물들이 마우스 대식세포 RAW 264.7 세포주의 성장에 미치는 영향을 연구하기 위해 cell viability assay를 수행하였다. 우선 96 well plate에 $1 \times 10^{5}$ 개의 RAW 264.7 세포를 접종한 후, 18 시간 동안 배양하였다. 그 후 $\mathrm{DMSO}$ 에 녹인 추출물 및 분획물을 각각 $500 \mu \mathrm{g} / \mathrm{ml}$ (1차 40종) 혹은 $150 \mu \mathrm{g} / \mathrm{ml}$ (2차 45종) 으로 처리하였다. 16시간 후, cell viability assay를 수행하기 위해 MTS (3-(4,5-dimethylthiazol-2-yl)5-(3-carboxy-methoxyphenyl)-2-(4-sulfophenyl)$2 \mathrm{H}$-tetrazolium)용액(Promega, USA)을 각 well당 $20 \mu \mathrm{l}$ 씩 첨 가하여 $37^{\circ} \mathrm{C}, 5 \% \mathrm{CO}_{2}$ incubator에서 4 시간 동안 반응시켰다. 반응이 끝난 후 NanoQuant Plate ${ }^{\mathrm{TM}}$ (Tecan Trading AG, Switzerland)를 사용하여 $580 \mathrm{~nm}$ 에서 흡광도를 측정하였다. 실험결과 수치는 4 개의 독립적인 well에서 수행한 값을 Microsoft EXCEL program을 이용하여 분석한 후 mean $\pm \mathrm{SD}$ 값과 그래프로 나타내었다.

\section{Total RNA 추출}

Total RNA 추출은 주박 및 추출물을 처리 배양된 RAW 264.7 세포로부터 RNeasy mini kit (Qiagen, USA)을 이용하여 제조사의 매뉴얼에 따라 수행하였다. 최종단계에서는 잘 건조 된 column을 새로운 $1.5 \mathrm{ml}$ collection tube에 옮기고 RNase-free water $40 \mu 1$ 를 첨가하여 10,000 rpm에서 1분 동안 원심분리 하여 RNA 용액을 얻었다. 정제된 total RNA는 NanoQuant Plate ${ }^{\mathrm{TM}}$ 를 이용하여 $260 \mathrm{~nm}$ 와 $280 \mathrm{~nm}$ 에서 흡광 도를 측정하였다. 정량한 RNA는 reverse-transcription PCR, oligo DNA microarray 실험 및 정량적 real-time PCR에 사용 하였다.

\section{Oligo DNA microarray 실험}

Oligo DNA microarray 실험과 결과 분석은 지노믹트리사 (Genomictree, Inc, Korea)에 위탁하여 수행하였으며, 사용한 microarray는 Agilent사의 Agilent Mouse GE 4 X 44K (V2) arrays (Agilent Techonlogies, Palo Alto, USA)를 사용하였다.

\section{Reverse transcription-PCR과 정량적 real-time PCR} RT-PCR은 PrimeScript ${ }^{\mathrm{TM}}$ RT-PCR Kit (TaKaRa, Japan)를 이용하여 제조사의 매뉴얼에 따라 수행하였다. 정량적 real-time PCR은 ABI prism 7500 cycler (Applied Biosystem USA)를 이용하여 수행하였다. 사용된 primer들은 Table 3 과 같으며, PCR mixture는 Power SYBR® Green PCR Master Mix (Applied Biosystem, USA) $10 \mu \mathrm{l}$, forward primer $1 \mu \mathrm{l}$, reverse primer $1 \mu \mathrm{l}$, 증류수 $1 \mu \mathrm{l}$ 를 첨가하여 최종부피를 15 
Table 3. Sequences of oligonucleotide primers used for RT-PCR and quantitative real time PCR

\begin{tabular}{|c|c|c|}
\hline Gene Name & GenBank Acc. NO. & Sequence \\
\hline$G A P D H$ & NM_008084.2 & $\begin{array}{l}\text { F : 5'-GAACGTGAAGCCCATCGAGG-3' } \\
\text { R : 5'-GTCCTTGTAGATCTCCTGGA-3' }\end{array}$ \\
\hline iNOS & NM_010927.3 & $\begin{array}{l}\text { F : 5'-CTGCAGCACTTGGATCAGGAACCTG-3' } \\
\mathrm{R}: \text { 5'-GGGAGTAGCCTGTGTGCACCTGGAA-3' }^{\prime}\end{array}$ \\
\hline TNF-alpha & NM_013693.2 & $\begin{array}{l}\text { F : 5'-CGTCAGCCGATTTGCTATCT-3' } \\
\text { R : 5'-CGGACTCCGCAAAGTCTAAG-3' }\end{array}$ \\
\hline $\operatorname{COX}-2$ & NM_011198.3 & $\begin{array}{l}\text { F : 5'-CCGTGGTGAATGTATGAGCA-3' } \\
\text { R : 5'-CCTCGCTTCTGATCTGTCTT-3' }\end{array}$ \\
\hline IL-10 & NM_010548 & $\begin{array}{l}\text { F: 5'-CTGCTATGCTGCCTGCTCTTACT-3' } \\
\text { R: 5'-CCGCAGCTCTAGGAGCATGT-3' }\end{array}$ \\
\hline$I L-1 F 6$ & NM_019450 & $\begin{array}{l}\text { F: 5'-CACTGCAGTCCCAAGGAAAGAG-3' } \\
\text { R: 5'-GGCCTTTGCACTCCCATGTA-3' }\end{array}$ \\
\hline$I L-1 R N$ & NM_001039701 & $\begin{array}{l}\text { F: 5'-TCTTACTCATCCCTGTGACTTTGG-3' } \\
\text { R: 5'-AATCTCCCGCCCTTTCTGTT-3' }\end{array}$ \\
\hline NOS2 & NM_010927 & $\begin{array}{l}\text { F: 5'-CTGCAGCACTTGGATCAGGAACCTG-3' } \\
\text { R: 5'-GGGAGTAGCCTGTGTGCACCTGGAA-3' }\end{array}$ \\
\hline Fabpt & NM_024406 & $\begin{array}{l}\text { F: 5'-CATCAGCGTAAATGGGGATT-3' } \\
\text { R: 5'-TCGACTTTCCATCCCACTTC-3' }\end{array}$ \\
\hline CSF2 & NM_009969 & $\begin{array}{l}\text { F: 5'-AGGAGGATGTGGCTGCAGAA-3' } \\
\text { R: 5'-TTCTTTGATGGCCTCTACATGCT-3' }\end{array}$ \\
\hline
\end{tabular}

$\mu 1$ 로 하였고 PCR mixture $15 \mu$ 와 cDNA $5 \mu 1$ 를 96 well optical reaction plate에 첨가하여 $\mathrm{PCR}$ 반응의 최종부피를 $20 \mu 1$ 로 하였다. Optical adhesive covers (Applied Biosystem, USA)를 이용하여 plate를 덮고 real-time PCR machine (Applied Biosystem, USA)을 이용하여 PCR 반응을 수행하였다. 반응 조건은 첫 번째 step으로 $50^{\circ} \mathrm{C}$ 에서 2 분, $95^{\circ} \mathrm{C}$ 에서 10 분간 반응 시키고, 두 번째 step으로 $95^{\circ} \mathrm{C}$ 에서 15 초, $58^{\circ} \mathrm{C}$ 에서 30 초, $72^{\circ} \mathrm{C}$ 에서 33초의 cycle을 40 번 반복하여 수행하였다. 결과는 Microsoft Excel을 이용하여 분석, 정량 하였으며, 분석법으로 는 comparative Ct (threshold cycle) 방법을 이용하였다. 데이 터의 분석은 이전에 발표된 논문에 의거하여 수행하였다[12].

\section{결과 및 고찰}

\section{5종의 주박 추출물 및 분획물이 NO생성과 세포생존율에} 미치는 영향

LPS 처리에 의해 염증이 유도된 RAW 264.7 세포주에서 nitric oxide (NO) 생성을 측정하기 위해 $0.2 \mu \mathrm{g} / \mathrm{ml}$ 의 LPS로 염증을 유도하고, 40 종의 1차 추출물 및 분획물을 $500 \mu \mathrm{g} / \mathrm{ml}$ 의 농도로 처리한 다음 nitric oxide assay를 수행하였다. 유기 용매 분획물의 대조물질로는 용매인 $\mathrm{DMSO}$ 를 이용하였다. 또 한 세포생존율을 측정하기 위해 nitric oxide assay에서 실시한 동일한 조건으로 분획물을 RAW 264.7 세포주에 처리한 후 cell viability assay를 수행하였다. 그 결과 LPS로 염증을 유도 하면 6배 $\mathrm{NO}$ 생성량이 증가되었고, 염증을 유도한 후 40 종의
추출물 및 분획물을 처리한 결과 대부분의 분획물에 의해 $\mathrm{NO}$ 생성이 감소되는 것을 확인할 수 있었다. 특히 KSD-E6-2, KSD-E6-3, KSD-E3-2, KSD-E3-3, KSD-E1-3 등 몇몇의 분획물 에서 $\mathrm{NO}$ 생성이 크게 감소한 것을 확인할 수 있었다(Fig. 1A). 그러나, 동일한 주박 추출물에 의해 세포 생존율도 크게 감소 하는 것으로 확인되어, 세포 생존율의 감소에 의해 $\mathrm{NO}$ 생성이 억제되는 것으로 확인되었다(Fig. 1B).

2 차 분획물 45 종에 의한 nitric oxide $(\mathrm{NO})$ 생성을 측정하기 위해 RAW 264.7 세포주에 $0.2 \mu \mathrm{g} / \mathrm{ml}$ LPS로 염증을 유도하고, 추출물 및 분획물을 $150 \mu \mathrm{g} / \mathrm{ml}$ 와 LPS를 처리한 후 nitric oxide assay를 수행하였다. 주박 분획물의 대조물질로는 용매인 $\mathrm{DMSO}$ 를 처리하였다. 세포생존율 측정은 동일한 방법으로 cell viability assay를 수행하였다.

그 결과 LPS로 염증을 유도하면 6배 $\mathrm{NO}$ 생성량이 증가되 었고, 염증을 유도한 후 45 종의 추출물 및 분획물을 처리한 결 과 KSD-E4-1, KSD-E4-2, KSD-E4-3, KSD-E7-3, KSD-E10-2, KSD- E8-3, KSD-E9-2, KSD-E9-3, KSD-W8-3 분획물에서 NO 생성이 감소되는 것을 확인할 수 있었다(Fig. 1C). Cell viability assay 결과에서는 모든 분획물 처리에 의해 세포생존율 에 큰 변화가 없는 것으로 확인할 수 있었다(Fig. 1D). 1차 및 2 차 연구결과를 종합하여 총 85 종의 주박 추출물 및 분획물 중 3종을(KSD-E1-3, KSDE2-3 그리고 KSD-E4-3) 최종 선별하 여 추후 연구를 진행하였다. 
A

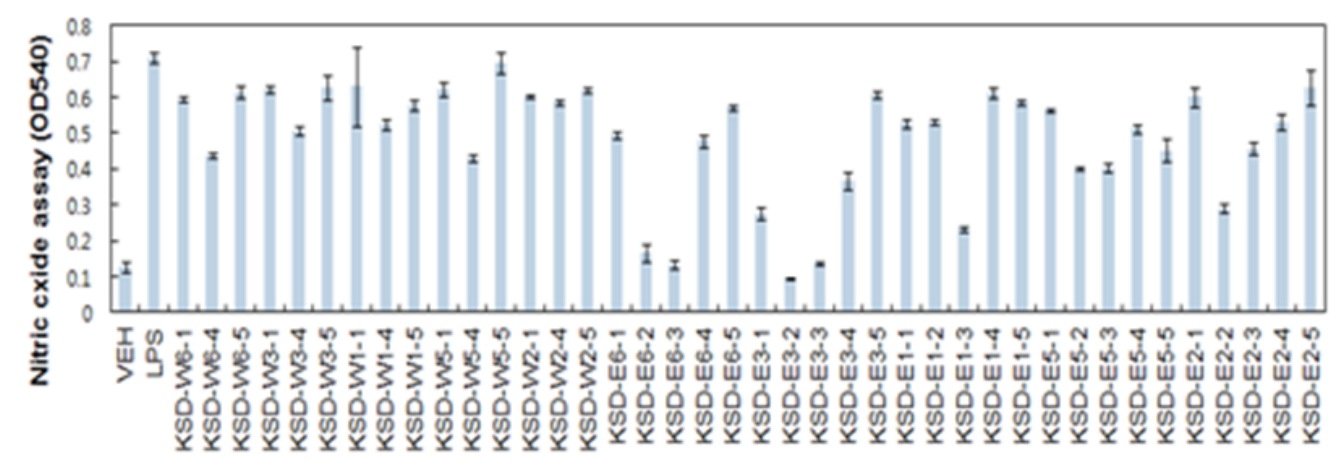

B

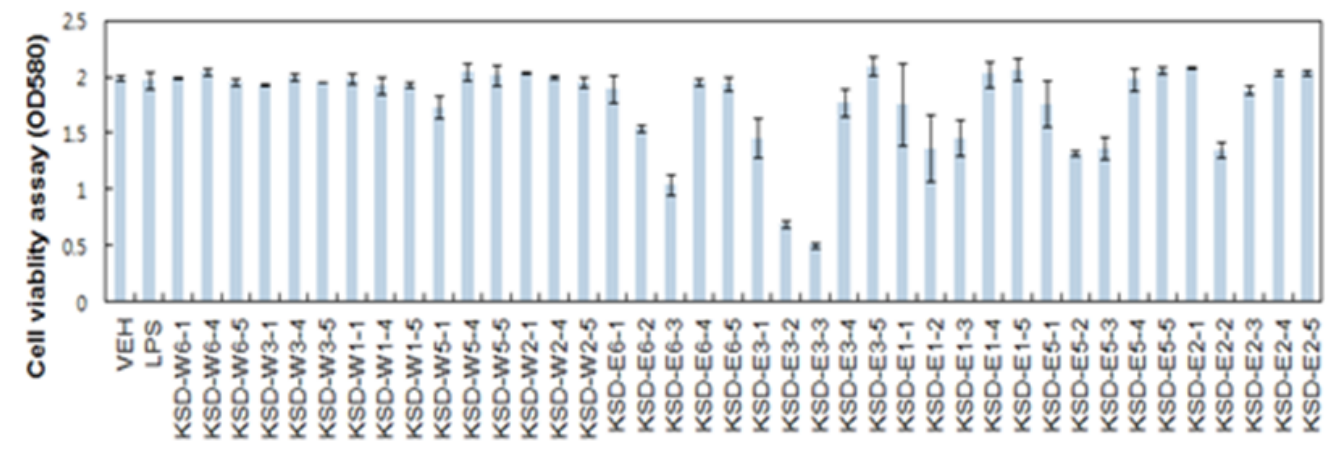

C

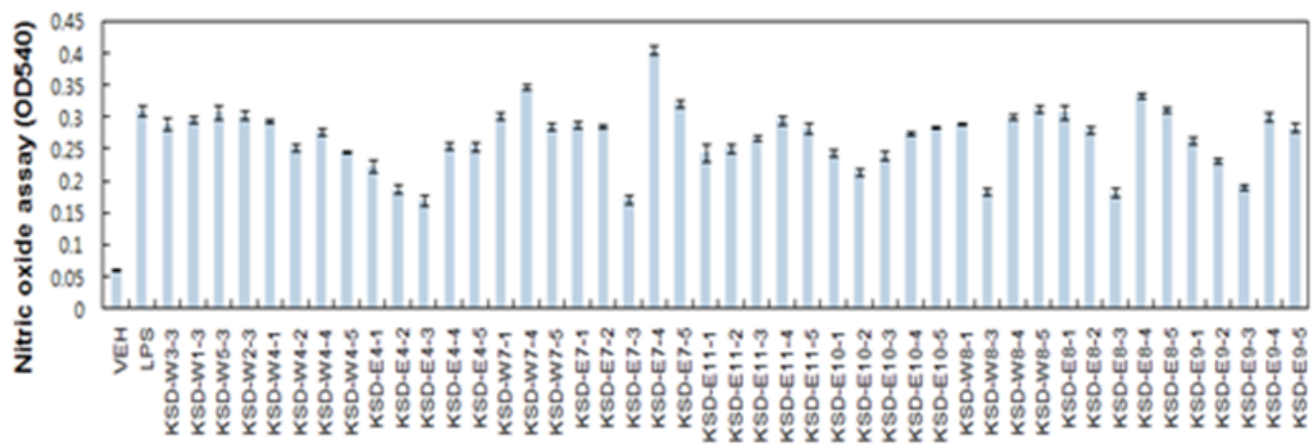

D

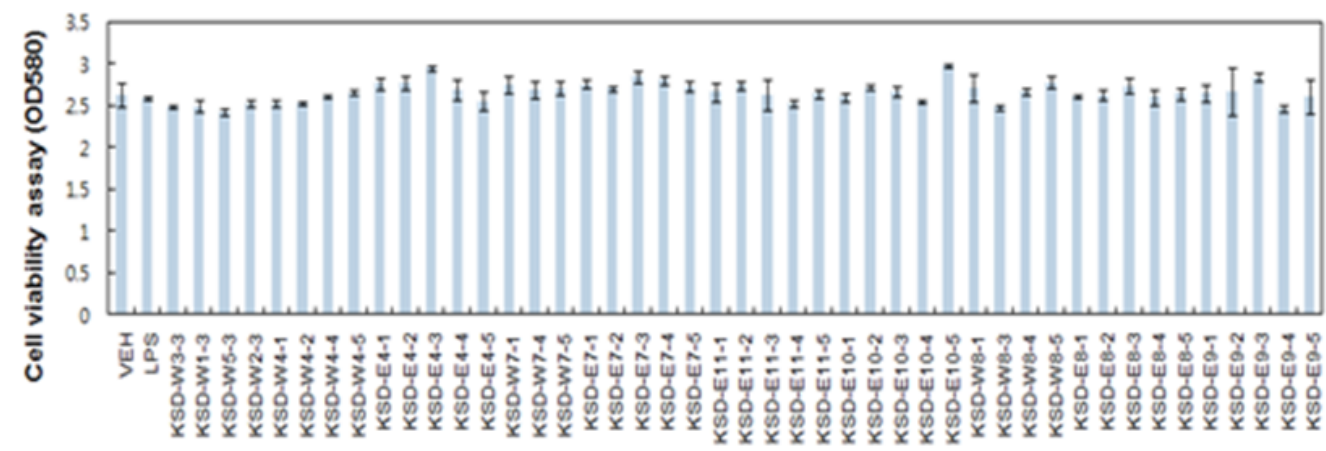

Fig. 1. Effects of eighty five kinds of lees extracts and their solvent fractions on production of nitric oxide (A, C) and cell viabilities (B, D) in RAW 264.7 cells. RAW 264.7 cells were treated with lees extracts and their solvent fractions $(500 \mu \mathrm{g} / \mathrm{ml}(\mathrm{A}, \mathrm{B})$ and $150 \mu \mathrm{g} / \mathrm{ml}(\mathrm{C}, \mathrm{D}))$ for $18 \mathrm{hr}$. After treatment, nitric oxide production was measured by nitric oxide assay and cell viability was measured using MTS proliferation assay kit.

\section{선별된 3종 분획물의 농도별 nitric oxide (NO) 생성과 세포생존율 측정}

선별된 3종(KSD-E1-3, KSDE2-3, KSD-E4-3)의 주박의 유기 용매 분획물 농도에 따른 NO 생성 저해 여부와 RAW 264.7 세포 성장에 미치는 영향을 연구하였다. 즉, RAW 264.7 세포
주에 $0.2 \mu \mathrm{g} / \mathrm{ml} \mathrm{LPS}$ 를 처리하여 염증을 유도한 후, 3종의 분획 물을 100, 150, $200 \mu \mathrm{g} / \mathrm{ml}$ 의 농도로 처리하여 NO 생성을 측정 하였다. 또한 세포생존율을 측정하기 위하여 동일한 조건으로 3종의 분획물을 처리한 후, cell viability assay를 수행하였다. 그 결과, 분획물 KSD-E1-3, KSD-E4-3를 처리한 경우 농도 의 

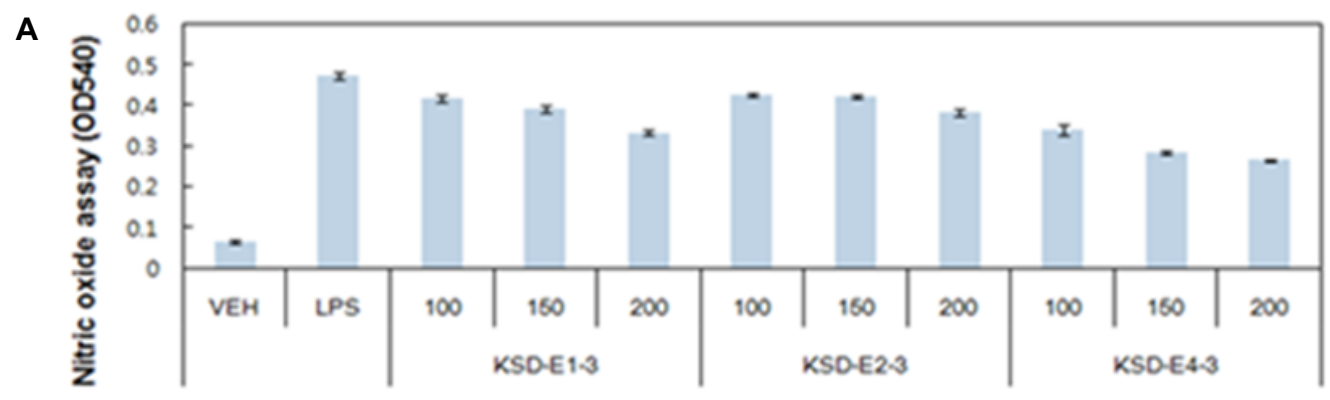

LPS + sample $(\mu g / m$ l)

B

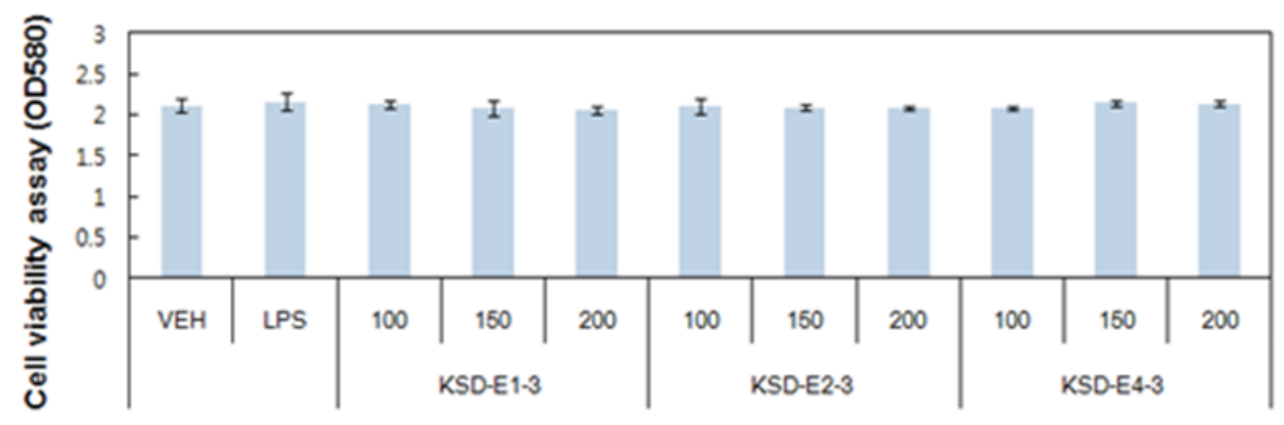

LPS + sample $(\mu \mathrm{g} / \mathrm{ml})$

Fig. 2. Suppressive effects of selected three kinds of lees extracts and their solvent fractions on production of nitric oxide (A) in RAW 264.7 cells without affecting cell viability (B). RAW 264.7 cells were treated with three different concentrations (100, 150 , and $200 \mu \mathrm{g} / \mathrm{ml}$ ) of three kinds of solvent fractions for $18 \mathrm{hr}$. After treatment, nitric oxide production was measured by nitric oxide assay and cell viability was measured using MTS proliferation assay kit.

존적으로 $\mathrm{NO}$ 생성이 감소되는 것을 확인할 수 있었다(Fig. 2A). 반면, cell viability assay 결과에서는 처리한 3종의 분획 물에 의한 세포 생존율에 미치는 영향은 미미한 것으로 확인 되었다(Fig. 2B).

\section{선별된 3종의 주박 추출물 및 분획물에 의한 $i N O S, C O X-2$,} TNF-alpha 유전자의 발현 연구

선별된 3종의 주박 분획물(KSD-E1-3, KSD-E2-3, KSD-E4-3) 에 의한 염증 유도에 관련된 iNOS, TNF-alpha, COX-2 유전자 의 발현 변화를 확인하였다(Fig. 3). 즉, 염증이 유도된 RAW 264.7 세포주에 주박 추출물을 $150 \mu \mathrm{g} / \mathrm{ml}$ 의 농도로 각각 처리

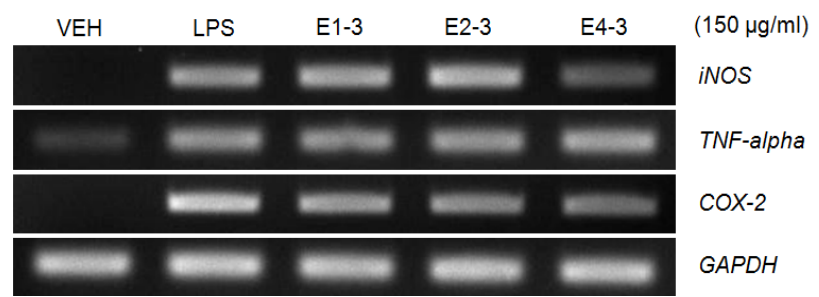

Fig. 3. Down-regulation of $i N O S, T N F-a l p h a$, and COX-2 genes by three kinds of solvent fractions. RAW 264.7 cells were treated with three kinds of solvent fractions (KSD-E1-3, KSDE2-3, and KSD-E4-3). Total RNA was prepared for RT-PCR with each gene specific primers.
한 후, 각 유전자 특이적인 primer (Table 3)를 이용하여 RT-PCR을 수행하였다. 그 결과, KSD-E4-3 분획물의 처리에 의해 $i N O S$ 유전자와 $C O X-2$ 유전자의 발현이 현저하게 감소 함을 확인 할 수 있었다. 반면, TNF-alpha 유전자의 발현은 큰 변화가 없는 것으로 확인 되었다.

\section{Oligo DNA microarray를 이용한 유전체 수준에서의 유 전자 발현 분석 및 염증관련 유전자 발현 분석}

주박 유기용매 분획물 KSD-E4-3에 의한 마우스 대식세포 RAW 264.7 세포주에서 nitric oxide (NO) 생성 저해 활성을 유전자 발현 수준에서 이해하고자, 염증이 유도된 RAW 264.7 세포주에 $150 \mu \mathrm{g} / \mathrm{ml}$ 의 KSD-E4-3 주박 분획물을 처리한 후, oligo DNA microarray 실험을 수행하였다. DNA microarray 실험 결과, 염증 유도와 관련이 있는 유전자 중 2 배 이상 발현 이 감소하는 유전자 6개(interleukin 1 family, member 6 [IL-1F6], nitric oxide synthase 2, inducible [iNOS], interleukin 10 [IL-19], fatty acid binding protein 4, adipocyte [Fabp4], interleukin 1 receptor antagonist [IL-1RM, colony stimulating factor 2 (granulocyte-macroph-age) [CSF2])를 선 택하여 RT-PCR을 수행하였다. Fig. 4A에서 제시한 바와 같이 $150 \mu \mathrm{g} / \mathrm{ml}$ 의 KSD-E4-3 처리에 의해 $I L-1 F 6, i N O S, I L-10$, $F A B P 4, I L-1 R N$, 그리고 CSF2의 유전자의 발현이 모두 downregulation 되는 것으로 확인되었다. 이러한 결과는 DNA mi- 

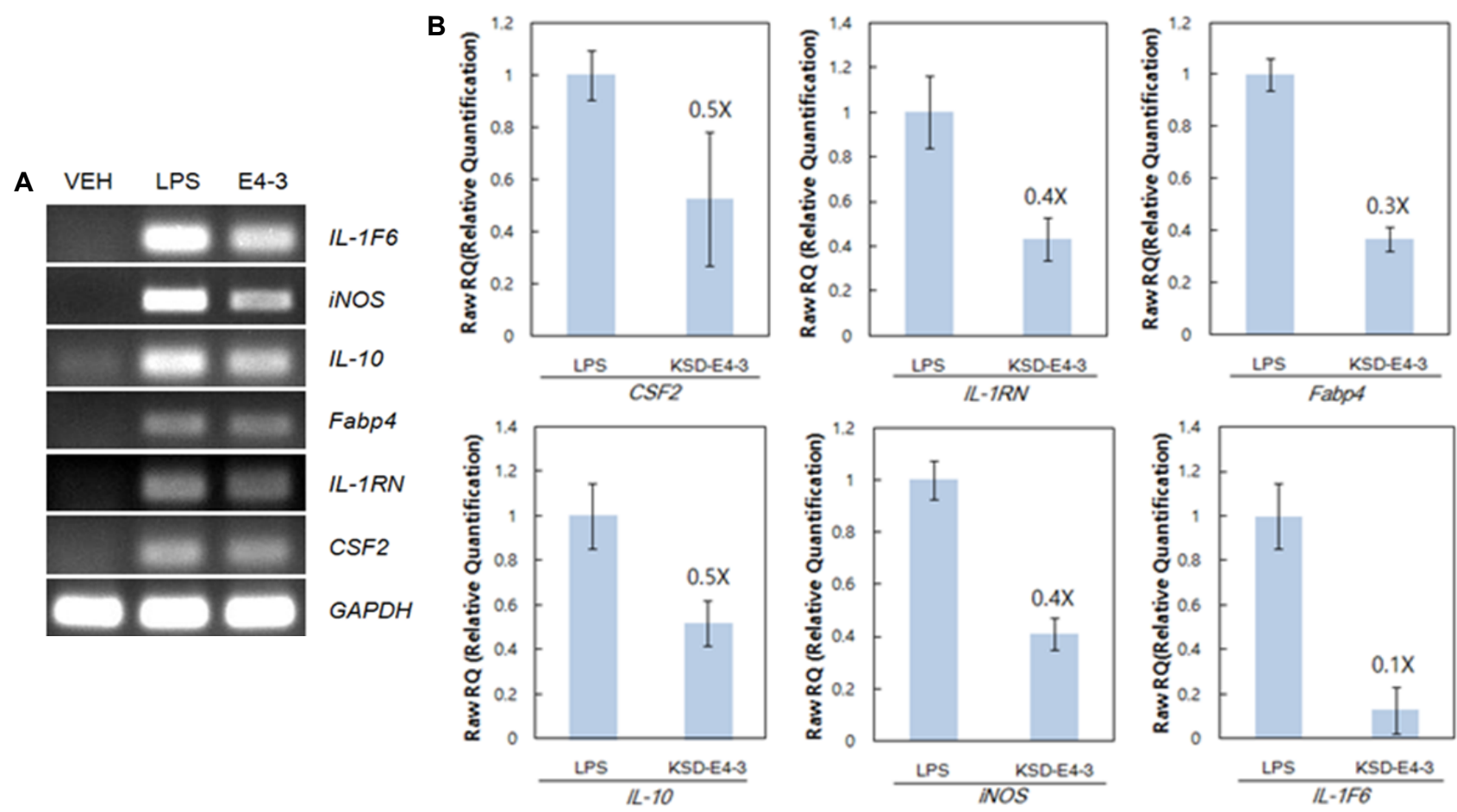

Fig. 4. Confirmation of microarray data with RT-PCR and real-time PCR. Mouse RAW 264.7 cells were treated with $150 \mu \mathrm{g} / \mathrm{ml}$ of KSD-E4-3 and $0.2 \mu \mathrm{g} / \mathrm{ml}$ LPS. (A) Total RNA was prepared and used as a template for RT-PCR using gene specific primers. (B) Total RNA was prepared from treated cells and used as a template for real-time PCR with CSF2, IL-1RN, Fabp4, IL-10, iNOS, and IL-1F6 gene-specific primers.

croarray 실험 결과와 모두 일치하였다. 이러한 유전자의 발현 을 정량적으로 확인하기 위하여 real-time PCR을 수행하였다.

그 결과, 유전자 발현변화가 CSF2에서 0.5 배, $I L-1 R N$ 에서 0.4

배, Fabp4에서 0.3배, IL-10에서 0.5배, iNOS에서 0.4배, IL-1F6 에서 0.1 배로 유전자 발현이 감소된 것을 확인할 수 있었다 (Fig. 4B). 이러한 연구결과를 종합하면, 주박 추출물 및 이의 유기용매 분획물에 의한 항염증 활성은 염증 발생과 관련이 있는 여러 유전자의 발현을 억제함으로써 작용함을 시사한다. 또한, 향후 KSD-E4-3분획물의 추가적인 분획 및 분리방법을 통하여 이러한 분획물에 포함되어 있는 핵심 물질을 찾아내는 연구가 지속되어야 할 것으로 생각된다.

\section{감사의 글}

본 연구는 2012년도 농림수산식품부 고부가가치식품기술 개발사업(과제번호 112073-3)에 의해 수행되었으며, 이에 감 사드립니다.

\section{References}

1. Akira, S. and Takeda, K. 2004. Toll-like receptor signalling. Nat Rev Immunol 4, 499-511.

2. Chang, J. H. 1989. History of Korean spirits. Korean J Dietary Culture 4, 271-274.
3. Kim, J. E., Jung, S. K., Lee, S. J., Lee, K. W., Kim, G. W. and Lee, H. J. 2008. Nuruk extract inhibits lipopolysaccharide-induced production of nitrite and interleukin-6 in RAW 264.7 cells through blocking activation of p38 mitogen-activated protein kinase. J Microbiol Biotechnol 18, 1423-1426.

4. Kim, K. S., Cui, X., Lee, D. S., Sohn, J. H., Yim, J. H., Kim, Y. C. and Oh, H. 2013. Anti-inflammatory effect of neoechinulin A from the marine fungus Eurotium sp. SF-5989 through the suppression of NF- $\mathrm{KB}$ and p38 MAPK pathways in lipopolysaccharide-stimulated RAW 264.7 macrophages. Molecules 18, 13245-13259.

5. Kim, S. M. and Cho, W. K. 2006. Effects of Takju (Korean turbid rice wine) lees on the serum glucose levels in streptozotocin induced diabetic rats. Korean J Food Culture 21, 638643.

6. Kim, T. Y., Jeon, T. W., Yeo, S. H., Kim, S. B., Kim, J. S. and Kwak, J. S. 2010. Antimicrobial, antioxidant and SOD-like activity effect of jubak extracts. Korean J Food Nutr 23, 299-305.

7. Kindt, T. J., Goldsby, R. A. and Osborne, B. A. 2007. Innate immunity: Tenney S. Kuby Immunology, pp. 52-73, 6th ed., Freeman \& Co., NY, USA.

8. Kwon, S. C., Jeon, T. W., Park, J. S., Kwak, J. S. and Kim, T. Y. 2012. Inhibitory effect on tyrosinase, ACE and xanthine oxidase, and nitrite scavenging activities of jubak (alcohol filter cake) extracts. J Korean Soc Food Sci Nutr 41, 1191-1196. 
9. Lee, D. Y., Lee, S. J., Kwak, H. Y., Jung, L., Heo, J., Hong, S., Kim, G. W. and Baek, N. I. 2009. Sterols isolated from nuruk (Rhizopus oryzae KSD-815) inhibit the migration of cancer cells. J Microbiol Biotechnol 19, 1328-1332.

10. Lee, J. H., Park, S. M., Jung, H. J., Kim, H. S. and Yu, T. S. 2007. Characteristics of Ju-back and effect of Ju-back fertilizer on growth of crop plants. J Life Sci 17, 1562-1570.

11. Lee, S. J., Cho, S. W., Kwon, Y. Y., Kwon, H. S. and Shin, W. C. 2012. Inhibitory effects of ethanol extracts from nuruk on oxidative stress, melanogenesis, and photo-aging. Mycobiology 40, 117-123.

12. Livak, K. J. and Schmittgen, T. D. 2001. Analysis of relative gene expresstion date using real-time quantitative PCR and the 2- $\triangle \triangle \mathrm{CT}$ Method. Methods 25, 402-408.

13. Lowenstein, C. J. and Snyder, S. H. 1992. Nitric oxide, a novel biologic messenger. Cell 70, 705-707.

14. Monick, M. M., Carter, A. B., Robeff, P. K., Flaherty, D. M.,
Peterson, M. W. and Hunninghake, G. W. 2001. Lipopolysaccharide activates Akt in human alveolar macrophages resulting in nuclear accumulation and transcriptional activity of beta-catenin. I Immunol 166, 4713-4720.

15. Sung, M. J., Davaatseren, M., Kim, W., Park, S. K., Kim, S. H., Hur, H. J., Kim, M. S., Kim, Y. S. and Kwon, D. Y. 2009. Vitisin A suppresses LPS-induced NO production by inhibiting ERK, p38, and NF-kappaB activation in RAW 264.7 cells. Int Immunopharmacol 9, 319-323.

16. Yang, S., Lee, J., Kwak, J., Kim, K., Seo, M. and Lee, Y. W. 2011. Fungi associated with the traditional starter cultures used for rice wine in Korea. J Korean Soc Appl Biol Chem 54, 933-943.

17. Yu, T. S., Yeo, S. H. and Kim, H. S. 2004. A new species of Hyphomycetes, Aspergillus coreanus sp. nov., isolated from traditional Korean nuruk. J Microbiol Biotechnol 14, 182-187.

\title{
초록 : 주박 추출물과 이들의 유기용매 분획물에 의한 항염증 활성
}

\author{
박미정 ${ }^{1} \cdot$ 강형택 $^{1} \cdot$ 김미선 ${ }^{2} \cdot$ 신우창 $^{3} \cdot$ 손호용 $^{2} \cdot$ 김종식 $^{1 *}$ \\ ( ${ }^{1}$ 국립안동대학교 생명과학과, ${ }^{2}$ 국립안동대학교 식품영양학과, ${ }^{3}$ (주국순당 연구소)
}

본 연구에서는 전통주 제조시 부산물로 생산되는 주박과 누룩으로부터 추출물과 유기용매 분획물을 총 85종을 제조하고, 이들에 의한 항염증 활성을 연구하였다. 85종의 분획물 중 선별한 세 가지의 분획물(KSD-E1-3, KSD-E2-3, KSD-E4-3)에 의해서 LPS에 의해 염증이 유도된 RAW 264.7 세포주에서 nitric oxide 생산이 현저히 감소됨을 확인하였다. 또한, 세가지 분획물에 의해 염증유발 유전자인 COX-2, TNF-alpha, 그리고 iNOS 유전자의 발현이 감소되었다. 세 가지 분획물 중 KSD-E4-3에 의한 항염증 활성의 작용기전을 이해하기 위하여 oligo DNA microarray를 수행하였다. 마이크로어레이 결과 발현이 감소된 유전자 중 염증과 관련된 유전자 6개(IL-1F6, iNOS, IL-10, Fabp4, IL-1RN, CSF2)를 선택하여, RT-PCR과 정량적 real-time PCR을 수행하였다. 그 결과, 모든 유 전자의 발현이 감소됨을 확인하였다. 결론적으로, 이러한 연구결과는 전통주 주박이 항염증 활성을 가지고 있는 식품이나 약품을 개발하는데 필요한 새로운 자원으로서 활용 가능함을 시사하는 것이다. 